\title{
Development of one-pot benzylic amination reactions of azine $\mathrm{N}$-oxides
}

\author{
Menekşe Liman ${ }^{a}$, Yunus Emre Türkmen ${ }^{\mathrm{a}, \mathrm{b}, *}$ \\ ${ }^{a}$ Department of Chemistry, Faculty of Science, Bilkent University, Ankara 06800, Turkey \\ ${ }^{\mathrm{b}}$ UNAM-National Nanotechnology Research Center and Institute of Materials Science and Nanotechnology, Bilkent University, Ankara 06800, Turkey
}

\section{A R T I C L E I N F O}

Article history:

Received 23 February 2018

Revised 20 March 2018

Accepted 21 March 2018

Available online 23 March 2018

Keywords:

Azine $\mathrm{N}$-oxides

Benzylic amination

One-pot synthesis

Heteroaromatic compounds

Amines

\begin{abstract}
A B S T R A C T
An efficient one-pot synthetic methodology has been developed for the benzylic amination reactions of methyl-substituted azine $\mathrm{N}$-oxides that operate under mild conditions. The reaction was found to tolerate quinoline and isoquinoline $\mathrm{N}$-oxides with electron donating and withdrawing substituents as the electrophilic reaction partners as well as a broad range of nucleophilic primary, secondary and aromatic amines, affording the benzylic amination products in up to $82 \%$ yield.
\end{abstract}

(ㄷ) 2018 Elsevier Ltd. All rights reserved.
During the last decade, there has been a renaissance of interest in the chemistry of azine $\mathrm{N}$-oxides, which enables efficient functionalization of a broad range of $N$-heteroaromatic compounds. ${ }^{1}$ In this context, azine $N$-oxides were shown to react successfully with a variety of carbon, ${ }^{2}$ nitrogen, ${ }^{3}$ oxygen, ${ }^{4}$ phosphorus ${ }^{5}$ and sulfur ${ }^{6}$-based nucleophiles as well as halides, ${ }^{7}$ generally in the presence of a suitable activating agent or a catalyst. Among various activating agents, PyBroP proved to be a particularly effective reagent for the activation of azine $\mathrm{N}$-oxides in a plethora of applications. $^{8}$

Whereas most of the recent synthetic efforts focused on the reactions of azines with nucleophiles at the 2-position, their functionalization at the benzylic position represents an equally important reaction class. In this regard, 2-(aminomethyl)azine derivatives are commonly encountered as ligands used in metal complexes, ${ }^{9}$ natural products such as Aplidiopsamine A (1), ${ }^{10}$ and many biologically active compounds such as BI 1356 (2), ${ }^{11}$ VUFK-8788 (3), ${ }^{12}$ and 4 (Fig. 1). ${ }^{13}$ One of the common methods for the functionalization of 2-methylazine compounds is via their radical bromination using NBS followed by nucleophilic substitution. . $^{\text {a,14 }}$ However, this reaction sometimes gives multiple bromination products, ${ }^{14}$ and may have selectivity issues in the presence of other functional groups. 2-Methylazines can also be oxidized to aldehydes at the benzylic position by $\mathrm{SeO}_{2}$ for further functionalization. ${ }^{15}$ One of the most widely employed methods

\footnotetext{
* Corresponding author at: Department of Chemistry, Faculty of Science, Bilkent University, Ankara 06800, Turkey.

E-mail address: yeturkmen@bilkent.edu.tr (Y.E. Türkmen).
}

for the derivatization of 2-methylazine $\mathrm{N}$-oxides is the Boekelheide rearrangement ${ }^{16}$ using acetic anhydride $\left(\mathrm{Ac}_{2} \mathrm{O}\right)^{17}$ and trifluoroacetic anhydride. ${ }^{18}$ While highly effective, these reactions may require high reaction temperatures, and more importantly, the 2-(acetoxymethyl)azine products of the rearrangement have to be hydrolyzed to the corresponding alcohols and further activated with suitable activating agents for their subsequent reactions with nucleophiles, all of which increase the overall number of steps. $^{9 \mathrm{~d}-\mathrm{f}, 13}$ In addition to acetic and trifluoroacetic anhydride, acyl chlorides, ${ }^{19}$ sulfonyl chlorides and sulfonic anhydrides ${ }^{20}$ and in situ-generated dialkylchlorophosphates ${ }^{21}$ have occasionally been used in Boekelheide-type rearrangements for the activation of azine $\mathrm{N}$-oxides.

In this work, we performed a systematic investigation on the activation of methyl-substituted azine $N$-oxides towards their reactions with amine nucleophiles, and developed an effective protocol for their one-pot benzylic amination reactions under mild conditions. Development of synthetic methodologies that operate in a one-pot manner has recently attracted significant attention from the synthetic community since such protocols eliminate the need for the purification of reaction intermediates and thus, lower the cost, reaction time, labour and waste generation. ${ }^{22,23}$

We initiated our study by screening a variety of activating agents for the targeted one-pot benzylic amination reaction (Table 1). Inspired by the recent successful utilization of PyBroP in a broad range of reactions as an activating agent for azine $\mathrm{N}$ oxides, ${ }^{8}$ we first tested this reagent in the reaction of quinaldine $\mathrm{N}$-oxide (5) with morpholine $(\mathbf{6})$ in acetonitrile at $80^{\circ} \mathrm{C}$. Disappointingly, the formation of the desired benzylic amination 


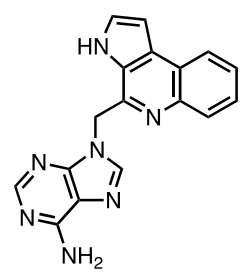

Aplidiopsamine A (1) Antiplasmodial alkaloid

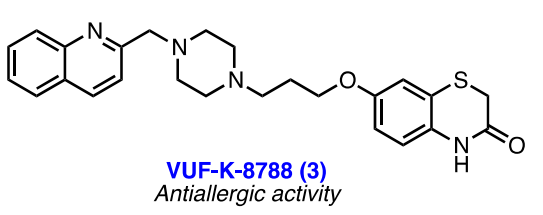

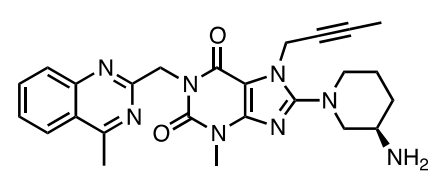

BI 1356 (Linagliptin) (2) Type /l diabetes treatment

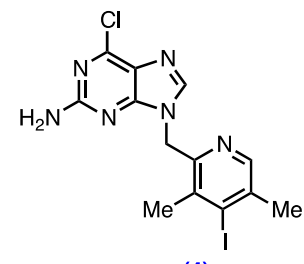

(4)
Fig. 1. Examples of biologically active 2-(aminomethyl)azine derivatives.

Table 1

Screening of activating agents for the one-pot benzylic amination reaction. ${ }^{a}$

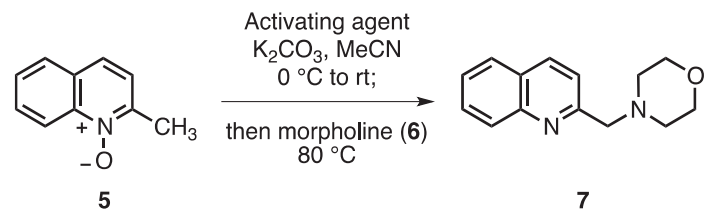

\begin{tabular}{lll}
\hline Entry & Activating agent & Yield $(\%)^{\mathrm{b}}$ \\
\hline 1 & $\mathrm{PyBroP}$ & $<5$ \\
2 & $\mathrm{Ph}_{3} \mathrm{PBr}_{2}$ & $<5$ \\
3 & $\mathrm{MsCl}$ & 71 \\
4 & $\mathrm{TsCl}$ & 81 \\
5 & $\mathrm{Ms}{ }_{2} \mathrm{O}$ & 67 \\
6 & $\mathrm{Ts}_{2} \mathrm{O}$ & 70 \\
7 & $\mathrm{Tf}_{2} \mathrm{O}$ & 7 \\
$8^{\text {c }}$ & $\mathrm{TsCl}$ & 80
\end{tabular}

${ }^{\text {a }}$ Reaction conditions: $0.31 \mathrm{mmol}$ of quinaldine $\mathrm{N}$-oxide $(\mathbf{5}), 0.37 \mathrm{mmol}$ of activating agent, $0.68 \mathrm{mmol}$ of $\mathrm{K}_{2} \mathrm{CO}_{3}, 0.47 \mathrm{mmol}$ of morpholine $(\mathbf{6})$ and $2.0 \mathrm{ml}$ of $\mathrm{MeCN}$.

b Yields were determined by ${ }^{1} \mathrm{H}$ NMR spectroscopy using 1,3,5-trimethoxybenzene as an internal standard.

c Activated $4 \AA$ molecular sieves were used. Abbreviations: PyBroP, bromotripyrrolidinophosphonium hexafluorophosphate; Ms, methanesulfonyl; Ts, p-toluenesulfonyl; Tf, trifluoromethanesulfonyl.

product 7 was not observed by the use of PyBroP (entry 1), and changing reaction parameters (solvent, temperature and base) did not provide any improvement. The use of another phosphonium salt, $\mathrm{Ph}_{3} \mathrm{PBr}_{2},{ }^{24}$ which is structurally related to PyBroP, gave a similar result and did not lead to the formation of 7 (entry 2). It should be noted that in these experiments, $\mathrm{N}$-oxide $\mathbf{5}$ was observed to remain almost completely unreacted at the end of the reactions. Based on these observations, we turned our attention to the use of sulfonyl chlorides and sulfonic anhydrides as activating agents for the desired transformation. Pleasingly, methanesulfonyl chloride $(\mathrm{MsCl})$ was found to be an effective promoter of the reaction providing the benzylic amination product 7 in $71 \%$ yield (entry 3 ). Switching to $p$-toluenesulfonyl chloride ( $\mathrm{TsCl}$ ) led to a further increase in reaction yield (81\%, entry 4 ). Next, we tested sulfonic anhydrides $\mathrm{Ms}_{2} \mathrm{O}$ and $\mathrm{Ts}_{2} \mathrm{O}$ in order to observe the effect of the counter anion $\left(\mathrm{Cl}^{-}\right.$, $\mathrm{MsO}^{-}$and $\left.\mathrm{TsO}^{-}\right)$formed upon the activation of the $\mathrm{N}$-oxide reactant. While still active, $\mathrm{Ms}_{2} \mathrm{O}$ and $\mathrm{Ts}_{2} \mathrm{O}$ gave slightly lower yields (67 and 70\% yields, respectively) compared to their $\mathrm{Cl}$-containing counterparts, $\mathrm{MsCl}$ and $\mathrm{TsCl}$ (entries 5 and 6).
The more reactive activating agent $\mathrm{Tf}_{2} \mathrm{O}$ gave rise to a complex mixture of products and afforded the amination product 7 in only 7\% yield (entry 7). Finally, the addition of $4 \AA$ molecular sieves did not provide an increase in the reaction yield when $\mathrm{TsCl}$ was used ( $80 \%$ yield, entry 8 ).

With the identification of $\mathrm{TsCl}$ as the optimal activating agent for the investigated one-pot benzylic amination reaction, we next performed a base, solvent and temperature screening (Table 2). When the reaction was run in acetonitrile at $80{ }^{\circ} \mathrm{C}, \mathrm{Na}_{2} \mathrm{CO}_{3}$ and $\mathrm{K}_{3} \mathrm{PO}_{4}$ gave inferior results compared to $\mathrm{K}_{2} \mathrm{CO}_{3}$ (entries 1-3). To our delight, switching the solvent to $\mathrm{CH}_{2} \mathrm{Cl}_{2}$ not only increased the yield to $90 \%$ but also demonstrated that the reaction operated well at a much lower temperature, $35^{\circ} \mathrm{C}$ (entry 4). In a control experiment, the yield of the amination product 7 was found to be $74 \%$ when the reaction was conducted in $\mathrm{MeCN}$ at $35^{\circ} \mathrm{C}$ (entry $5)$. Lower reaction yields were observed when THF and toluene were tested as solvents (64 and 27\%, respectively; entries 6 and 7). Benzotrifluoride $\left(\mathrm{PhCF}_{3}\right)$ was introduced by Curran and coworkers in 1997 as an alternative solvent to $\mathrm{CH}_{2} \mathrm{Cl}_{2}$ with a comparable polarity but higher boiling point. ${ }^{25}$ However, amination product 7 was obtained in 62 and 53\% yields, when the reaction was run in $\mathrm{PhCF}_{3}$ at 35 and $60{ }^{\circ} \mathrm{C}$, respectively (entries 8 and 9). The use of 2-MeTHF as a biorenewable, green solvent ${ }^{26}$ and TBME did not provide an improvement (entries 10 and 11). Finally, we focused on the effect of using organic amine bases instead of $\mathrm{K}_{2} \mathrm{CO}_{3}$ as an inorganic base. In this respect, $\mathrm{Et}_{3} \mathrm{~N}$, Hunig's base $\left(i \mathrm{Pr}_{2}-\right.$ $\mathrm{NEt}$ ) and $\mathrm{DBU}$ were tested in $\mathrm{CH}_{2} \mathrm{Cl}_{2}$ at $35^{\circ} \mathrm{C}$, but lower reaction yields were observed in each case (entries 12-14).

We next investigated the substrate scope of the developed benzylic amination reaction using the optimized conditions (Table 3 ). Initially, the performance of a variety of amines as the nucleophilic component of the reaction was tested systematically. Under the optimized reaction conditions, amination product $\mathbf{7}$ was obtained in $82 \%$ isolated yield after purification by column chromatography. Other cyclic secondary amines piperidine and pyrrolidine were found to be competent reaction partners giving the amination products 8 and $\mathbf{9}$ in $76 \%$ and $62 \%$ yields, respectively. Medicinally important piperazine moiety was incorporated to the amination reaction via the use of $\mathrm{N}$-Boc-piperazine, and the amination product 10 was isolated in $72 \%$ yield. The use of diethylamine amine as an acyclic secondary amine afforded product $\mathbf{1 1}$ in good yield (73\%). Cyclohexylamine and $\alpha$-methylbenzylamine were tested as primary amine nucleophiles, and were found to be successful reaction partners (46 and 64\% yields, respectively). Finally, we investigated pyrazole and imidazole as nitrogen-containing aromatic amine nucleophiles. While benzylic amination product 14 was obtained in $50 \%$ yield, the utilization of imidazole afforded the amination product 15 in a higher yield (61\%). These results demonstrate that a broad range of cyclic and acyclic secondary, primary and aromatic amines are successful nucleophilic reaction partners in the developed one-pot benzylic amination protocol.

Afterwards, we turned our attention to the investigation of various methyl-substituted azine $\mathrm{N}$-oxides in the amination reaction (Table 3 ). All the $N$-oxide derivatives tested in this study were prepared from the corresponding azine compounds through their oxidation by $m$-CPBA. ${ }^{28}$ The use of 6 -bromoquinaldine $N$-oxide gave product 16 in $66 \%$ isolated yield. The $\mathrm{Ar}-\mathrm{Br}$ moiety in this product has the potential to be utilized as a functional handle for further functionalization via a variety of cross-coupling reactions. The reaction tolerates the presence of the electron-donating -OMe group on the $\mathrm{N}$-oxide component, and the amination product was obtained in $47 \%$ yield. The use of 4 -chloroquinaldine $\mathrm{N}$-oxide substrate afforded product $\mathbf{1 8}$ in good yield (69\%). We next opted to test the reactivity of a substrate containing an amino group at the 4-position because of the importance of 4-dimethylaminopyridine (DMAP) analogues in organic chemistry. With this aim, the 
Table 2

Optimization of the one-pot benzylic amination reaction. ${ }^{a}$

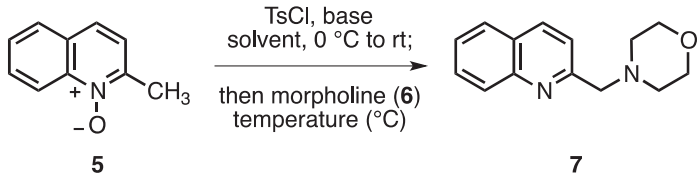

\begin{tabular}{lllll}
\hline Entry & Base & Solvent & Temperature $\left({ }^{\circ} \mathrm{C}\right)$ & Yield $(\%)^{\mathrm{b}}$ \\
\hline 1 & $\mathrm{~K}_{2} \mathrm{CO}_{3}$ & $\mathrm{MeCN}$ & 80 & 81 \\
2 & $\mathrm{Na}_{2} \mathrm{CO}_{3}$ & $\mathrm{MeCN}$ & 80 & 61 \\
3 & $\mathrm{~K}_{3} \mathrm{PO}_{4}$ & $\mathrm{MeCN}$ & 80 & 76 \\
4 & $\mathrm{~K}_{2} \mathrm{CO}_{3}$ & $\mathrm{CH}_{2} \mathrm{Cl}_{2}$ & 35 & 90 \\
5 & $\mathrm{~K}_{2} \mathrm{CO}_{3}$ & $\mathrm{MeCN}$ & 35 & 74 \\
6 & $\mathrm{~K}_{2} \mathrm{CO}_{3}$ & $\mathrm{THF}$ & 35 & 64 \\
7 & $\mathrm{~K}_{2} \mathrm{CO}_{3}$ & Toluene & 35 & 27 \\
8 & $\mathrm{~K}_{2} \mathrm{CO}_{3}$ & $\mathrm{PhCF}_{3}$ & 35 & 62 \\
9 & $\mathrm{~K}_{2} \mathrm{CO}_{3}$ & $\mathrm{PhCF}_{3}$ & 60 & 53 \\
10 & $\mathrm{~K}_{2} \mathrm{CO}_{3}$ & $2-\mathrm{MeTHF}_{1}$ & 60 & 34 \\
11 & $\mathrm{~K}_{2} \mathrm{CO}_{3}$ & $\mathrm{TBME}_{12}$ & 35 & 27 \\
13 & $\mathrm{Et}_{3} \mathrm{~N}$ & $\mathrm{CH}_{2} \mathrm{Cl}$ & 35 & 60 \\
14 & $i \mathrm{Pr}_{2} \mathrm{NEt}$ & $\mathrm{CH}_{2} \mathrm{Cl}_{2}$ & 35 & $<5$ \\
& $\mathrm{DBU}$ & $\mathrm{CH}_{2} \mathrm{Cl}_{2}$ & 35 & 13 \\
\hline
\end{tabular}

${ }^{a}$ Reaction conditions: $0.31 \mathrm{mmol}$ of quinaldine $\mathrm{N}$-oxide (5), $0.37 \mathrm{mmol}$ of $\mathrm{TsCl}$ $0.68 \mathrm{mmol}$ of base, $0.47 \mathrm{mmol}$ of morpholine (6) and $2.0 \mathrm{ml}$ of solvent.

b Yields were determined by ${ }^{1} \mathrm{H}$ NMR spectroscopy using 1,3,5-trimethoxybenzene as an internal standard. Abbreviations: DBU, 1,8-diazabicyclo[5.4.0]undec-7ene.

amination product 19 that possesses the doubly Boc-protected amino substituent was prepared successfully, albeit in a lower yield (40\%). Finally, 1 -methylisoquinoline $N$-oxide was found to be a compatible reaction partner affording the benzylic amination product $\mathbf{2 0}$ in 53\% yield, which demonstrates that the methodology can be extended to the synthesis of functionalized isoquinolines as well.

In order to assess the scalability of the one-pot protocol developed in this study, we next performed the benzylic amination reaction of quinaldine $N$-oxide $(\mathbf{5})$ on $10 \mathrm{mmol}$ scale $(1.59 \mathrm{~g})$, and the amination product 7 was isolated in 64 and 63\% yields on two trials (Scheme 1a). Even though there is a slight decrease in yield, these gram-scale experiments showcase the scalability and reproducibility of this one-pot method. When treated with $\mathrm{TsCl}$, a methyl-substituted azine $\mathrm{N}$-oxide first undergoes a Boekelheide-type rearrangement to give a (tosyloxymethyl)azine intermediate (21), which, without isolation, reacts subsequently with the nucleophilic amine component (Scheme 1b). When the reaction of quinaldine $\mathrm{N}$-oxide (5) was performed without the addition of an amine, 2-(tosyloxymethyl)quinoline (22) was isolated in $72 \%$ yield. ${ }^{28,29}$ It was reported that this reaction gave an imidazoquinoline side product with the incorporation of acetonitrile which was used as the reaction solvent. ${ }^{20 c}$ During the optimization studies, we also observed the formation of this side product in 6-25\% yield depending on the activating agent used when $\mathrm{MeCN}$ was the reaction solvent. ${ }^{28}$ The higher yields that we obtained with $\mathrm{CH}_{2} \mathrm{Cl}_{2}$ may be attributed to the lack of the formation of this side product. In another control experiment, the reaction between quinaldine $\mathrm{N}$-oxide and morpholine, performed under the optimized conditions but without $\mathrm{K}_{2} \mathrm{CO}_{3}$, gave product 7 in only $19 \%$ yield along with unreacted $\mathrm{N}$-oxide $\mathbf{5}^{30}$ Finally, 2 -picoline $\mathrm{N}$-oxide was found to be unreactive towards the Boekelheide-type rearrangement under the standard reaction conditions and did not provide the corresponding benzylic amination product.

In summary, we have developed a one-pot synthetic protocol that allows efficient benzylic amination reactions of methyl-substituted azine $\mathrm{N}$-oxides. This method is operationally simple, proceeds under mild reaction conditions and does not require the isolation of reaction intermediates. A broad range of cyclic and acyclic secondary, primary and aromatic amines as well as electron rich and deficient quinoline and isoquinoline $\mathrm{N}$-oxides are well tol-

Table 3

Substrate scope of the one-pot benzylic amination reaction ${ }^{27}$.

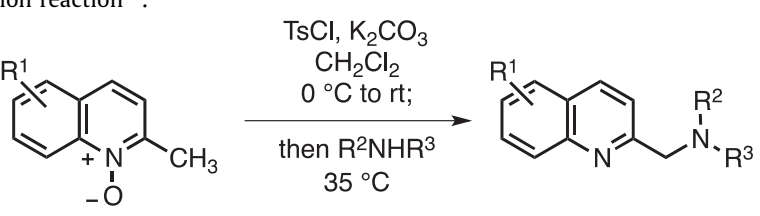<smiles>c1ccc2nc(CN3CCOCC3)ccc2c1</smiles>

7

$82 \%$<smiles>c1ccc2nc(CNC3CCCCC3)ccc2c1</smiles>

$46 \%$<smiles></smiles><smiles>CC(NCc1ccc2ccccc2n1)c1ccccc1</smiles><smiles>c1ccc2nc(CN3CCCC3)ccc2c1</smiles>

9<smiles>c1ccc2nc(Cn3cccn3)ccc2c1</smiles>

14
$50 \%$<smiles>CC(C)(C)OC(=O)N1CCN(Cc2ccc3ccccc3n2)CC1</smiles>

10<smiles>c1ccc2nc(Cn3ccnc3)ccc2c1</smiles>

15

$61 \%$<smiles>CCN(CC)Cc1ccc2ccccc2n1</smiles>

11<smiles>Brc1ccc2nc(CN3CCOCC3)ccc2c1</smiles>

16<smiles>COc1ccc2nc(CN3CCOCC3)ccc2c1</smiles>

a Reactions were carried out using azine $\mathrm{N}$-oxide (1.0 equiv), $\mathrm{TsCl}$ (1.4 equiv), $\mathrm{K}_{2} \mathrm{CO}_{3}$ (2.5 equiv) and amine base (2.0 equiv) in anhydrous $\mathrm{CH}_{2} \mathrm{Cl}_{2}$. Yields refer to isolated yields after purification by column chromatography. 
a.

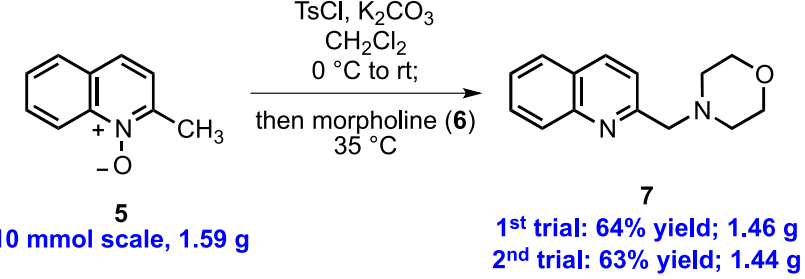

b.<smiles>[R1]c1ccc2c(ccc(C)[n+]2OC)c1</smiles><smiles>[R1]c1cccc2nc(C[O+])ccc12</smiles><smiles>[O+]Cc1ccc2ccccc2n1</smiles>

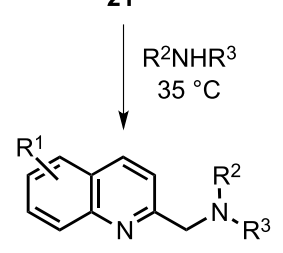

Scheme 1. Gram-scale example and description of the benzylic amination reaction.

erated in the reaction affording the benzylic amination products in up to $82 \%$ yield. Scalability of the method has been demonstrated through a gram-scale reaction. Given the importance of 2-(aminomethyl)azine derivatives as ligands and biologically active molecules, this one-pot protocol is expected to find widespread use in synthetic applications.

\section{Acknowledgments}

Financial support from the Scientific and Technological Research Council of Turkey (TÜBITAK; Grant No: 115Z865) is gratefully acknowledged.

\section{A. Supplementary data}

Supplementary data associated with this article can be found, in the online version, at https://doi.org/10.1016/j.tetlet.2018.03.062.

\section{References}

1. (a) Bull JA, Mousseau JJ, Pelletier G, Charette AB. Chem Rev. 2012;112:2642-2713;

(b) Larionov OV, ed. Heterocyclic N-Oxides. Springer; 2017.

2. (a) Andersson H, Banchelin TS-L, Das S, Olsson R, Almqvist F. Chem Commun. 2010;46:3384-3386;

(b) Andersson H, Olsson R, Almqvist F. Org Biomol Chem. 2011;9:337-346;

(c) Bering L, Antonchick AP. Org Lett. 2015;17:3134-3137;

(d) Jo W, Kim J, Choi S, Cho SH. Angew Chem Int Ed. 2016;55:9690-9694;

(e) Johnson TC, Marsden SP. Beilstein J Org Chem. 2016;12:1-4;

(f) Johnson TC, Marsden SP. Org Lett. 2016;18:5364-5367;

(g) Crisenza GEM, Dauncey EM, Bower JF. Org Biomol Chem. 2016;14:5820-5825;

(h) Zhang W-M, Dai J-J, Xu J, Xu H-J. J Org Chem. 2017;82:2059-2066;

(i) Zhang Z, Pi C, Tong H, Cui X, Wu Y. Org Lett. 2017;19:440-443;

(j) Han Y-P, Li X-S, Zhu X-Y, Li M, Zhou L, Song X-R, Liang Y-M. J Org Chem. 2017;82:1697-1704.

3. (a) Keith JM. J Org Chem. 2008;73:327-330;

(b) Keith JM. J Org Chem. 2010;75:2722-2725;

(c) Keith JM. J Org Chem. 2012;77:11313-11318;

(d) Farrell RP, Elipe MVS, Bartberger MD, Tedrow JS, Vounatsos F. Org Lett. 2013; 15:168-171;

(e) Rassadin VA, Zimin DP, Raskil'dina GZ, et al. Green Chem. 2016;18:6630-6636;

(f) Bugaenko DI, Yurovskaya MA, Karchava AV. J Org Chem. 2017;82:2136-2149;

(g) Yu X, Yang S, Zhang Y, Guo M, Yamamoto Y, Bao M. Org Lett. 2017; 19:6088-6091.

4. Jones DH, Kay ST, McLellan JA, Kennedy AR, Tomkinson NCO. Org Lett. 2017;19:3512-3515.
5. Wang H, Cui X, Pei Y, et al. Chem Commun. 2014;50:14409-14411.

6. Su Y, Zhou X, He C, Zhang W, Ling X, Xiao X. J Org Chem. 2016:81:4981-4987.

7. (a) Wengryniuk SE, Weickgenannt A, Reiher C, et al. Org Lett. 2013;15:792-795;

(b) Wang D, Jia H, Wang W, Wang Z. Tetrahedron Lett. 2014;55:7130-7132;

(c) Chen Y, Huang J, Hwang T-L, et al. Org Lett. 2015;17:2948-2951;

(d) Xiong H, Hoye AT, Fan K-H, et al. Org Lett. 2015;17:3726-3729;

(e) Qiao K, Wan L, Sun X, et al. Eur J Org Chem. 2016;1606-1611;

(f) Wang D, Wang Y, Zhao J, et al. Tetrahedron. 2016;72:5762-5768;

(g) Hossain M, Pradhan K, Nanda AK. Tetrahedron Lett. 2017;58:3772-3776.

8. (a) Londregan AT, Jennings S, Wei L. Org Lett. 2010;12:5254-5257;

(b) Londregan AT, Jennings S, Wei L. Org Lett. 2011;13:1840-1843;

(c) Londregan AT, Farley KA, Limberakis C, Mullins PB, Piotrowski DW. Org Lett. 2012;14:2890-2893;

(d) Lecointre B, Azzouz R, Bischoff L. Tetrahedron Lett. 2014;55:1913-1915; (e) Londregan AT, Burford K, Conn EL, Hesp KD. Org Lett. 2014;16:3336-3339; (f) Lian Y, Coffey SB, Li Q, Londregan AT. Org Lett. 2016;18:1362-1365;

(g) Aithagani SK, Kumar M, Yadav M, Vishwakarma RA, Singh PP. J Org Chem. 2016;81:5886-5894.

9. (a) Rieger B, Abu-Surrah AS, Fawzi R, Steiman M. I Organomet Chem. 1995;497:73-79;

(b) Wright DW, Mok HJ, Dubé CE, Armstrong WH. Inorg Chem 1998;37:3714-3718;

(c) Hanaoka K, Kikuchi K, Kojima H, Urano Y, Nagano T. I Am Chem Soc. 2004;126:12470-12476:

(d) Walton JW, Carr R, Evans NH, et al. Inorg Chem. 2012;51:8042-8056; (e) Gempf KL, Butler SJ, Funk AM, Parker D. Chem Commun. 2013;49:9104-9106:

(f) Neil ER, Funk AM, Yufit DS, Parker D. Dalton Trans. 2014;43:5490-5504.

10. Carroll AR, Duffy S, Avery VM. J Org Chem. 2010;75:8291-8294.

11. Eckhardt M, Langkopf E, Mark M, et al. J Med Chem. 2007;50:6450-6453.

12. (a) Takizawa T, Matsumoto J, Tohma T, et al. Jpn J Pharmacol. 2001;86:55-64; (b) Takizawa T, Watanabe C, Saiki I, Wada Y, Tohma T, Nagai H. Biol Pharm Bull. 2001;24:1127-1132.

13. Kasibhatla SR, Hong K, Biamonte MA, et al. J Med Chem. 2007;50:2767-2778.

14. (a) Tavares FX, Al-Barazanji KA, Bigham EC, et al. J Med Chem. 2006;49:7095-7107;

(b) Kuang G-C, Michaels HA, Simmons JT, Clark RJ, Zhu L. J Org Chem. 2010;75:6540-6548.

15. (a) Mathes W, Sauermilch W. Chem Ber. 1957;90:758-761;

(b) Yu X, Feng G, Huang J, Xu H. RSC Adv. 2016;6:30405-30411.

16. Tabolin AA, Ioffe SL. Chem Rev. 2014;114:5426-5476.

17. (a) Boekelheide V, Linn WJ. J Am Chem Soc. 1954;76:1286-1291;

(b) Lee KC, Chi DY. J Org Chem. 1999;64:8576-8581;

(c) Rádl S, Klecán O, Havlíček J. J Heterocyclic Chem. 2006;43:1447-1453.

18. (a) Pocker A. J Org Chem. 1973;38:4295-4299;

(b) Korytnyk W, Srivastava SC, Angelino N, Potti PGG, Paul B. J Med Chem 1973;16:1096-1101.

19. (a) Koenig T, Wieczorek JS. J Org Chem. 1968;33:1530-1532;

(b) Andreotti D, Miserazzi E, Nalin A, Pozzan A, Profeta R, Spada S. Tetrahedron Lett. 2010;51:6526-6530.

20. (a) Butera JA, Spinelli W, Anantharaman V, et al. I Med Chem. 1991;34:3212-3228;

(b) White JD, Yager KM, Stappenbeck F. J Org Chem. 1993;58:3466-3468; (c) Sledeski AW, O'Brien MK, Truesdale LK. Tetrahedron Lett. 1997;38:1129-1132;

(d) Rane RA, Pathak RK, Kaushik CP, Rao KVVP, Kumar A. Synth Commun 2002;32:1211-1217;

(e) Mori T, Satouchi Y, Tohmiya H, Higashibayashi S, Hashimoto K, Nakata M. Tetrahedron Lett. 2005;46:6417-6422;

(f) Lee J, Kang S-U, Kil M-J, et al. Bioorg Med Chem Lett. 2005;15:4136-4142.

21. Yang Y, Qu C, Chen X, et al. Org Lett. 2017;19:5864-5867.

22. Review: Hayashi Y. Chem Sci. 2016;7:866-880.

23. (a) Selected examples: Cameron M, Hoerrner RS, McNamara JM, Figus M Thomas S. Org Process Res Dev. 2006;10:149-152;

(b) Leggio A. Belsito EL, De Luca G, et al. RSC Adv. 2016:6:34468-34475;

(c) Leggio A, Belsito EL, Gallo S, Liguori A. Tetrahedron Lett. 2017;58:1512-1514.

24. (a) Wagner A, Heitz M-P, Mioskowski C. J Chem Soc Chem Commun. 1989;1619-1620;

(b) Salomé C, Kohn H. Tetrahedron. 2009;65:456-460.

25. Ogawa A, Curran DP. J Org Chem. 1997;62:450-451.

26. Pace V, Hoyos P, Castoldi L, de María PD, Alcántara AR. ChemSusChem. 2012:5:1369-1379.

27. Representative procedure for the benzylic amination reaction: Quinaldine $N$-oxide $5(200 \mathrm{mg}, 1.26 \mathrm{mmol})$ was dissolved in anhydrous $\mathrm{CH}_{2} \mathrm{Cl}_{2}(8.0 \mathrm{~mL})$ at rt under nitrogen. After the addition of $\mathrm{K}_{2} \mathrm{CO}_{3}(428 \mathrm{mg}, 3.10 \mathrm{mmol})$, the reaction mixture was cooled down to $0{ }^{\circ} \mathrm{C}$ in an ice-water bath. After five minutes, $\mathrm{TsCl}$ (332 mg, $1.74 \mathrm{mmol}$ ) was added, and it was stirred for five more minutes at this temperature. The cooling bath was removed, and the reaction mixture was stirred at rt for $5 \mathrm{~h}$. Morpholine ( $224 \mu \mathrm{L}, 2.52 \mathrm{mmol})$ was then added, and the reaction mixture was stirred at $35^{\circ} \mathrm{C}$ for $18 \mathrm{~h}$. After the mixture was cooled down to rt, water was added, and the aqueous phase was extracted three times with $\mathrm{CH}_{2} \mathrm{Cl}_{2}$. The combined organic phase was dried over $\mathrm{Na}_{2} \mathrm{SO}_{4}$, filtered and concentrated under reduced pressure. Purification by flash column chromatography $\left(\mathrm{SiO}_{2}, \mathrm{MeOH}: \mathrm{EtOAc}=1: 19\right)$ gave pure product 7 as a yellow oil $(234 \mathrm{mg}, 82 \%) . R_{f}=0.39(\mathrm{MeOH}$ : EtOAC $=1: 19) ;{ }^{1} \mathrm{H}$ NMR $\left(400 \mathrm{MHz} ; \mathrm{CDCl}_{3}\right) \delta$ $8.11(1 \mathrm{H}, \mathrm{d}, J=8.5 \mathrm{~Hz}), 8.07(1 \mathrm{H}, \mathrm{d}, J=8.5 \mathrm{~Hz}), 7.78(1 \mathrm{H}, \mathrm{d}, J=8.1 \mathrm{~Hz}), 7.68(1 \mathrm{H}$ 
ddd, $J=8.4,6.9$ and $1.4 \mathrm{~Hz}), 7.62(1 \mathrm{H}, \mathrm{d}, J=8.4 \mathrm{~Hz}), 7.50(1 \mathrm{H}, \mathrm{ddd}, J=8.1,7.0$ and $1.0 \mathrm{~Hz}), 3.83(2 \mathrm{H}, \mathrm{s}), 3.73(4 \mathrm{H}, \mathrm{t}, J=4.7 \mathrm{~Hz}), 2.55(4 \mathrm{H}, \mathrm{t}, J=4.6 \mathrm{~Hz}) ;{ }^{13} \mathrm{C} \mathrm{NMR}$ $\left(100 \mathrm{MHz} ; \mathrm{CDCl}_{3}\right) \delta: 159.2,147.8,136.5,129.5,129.2,127.6,127.5,126.3$, 121.2, 67.1, 65.7, 54.0; IR $v_{\max }$ (ATR, oil)/(cm ${ }^{-1}$ 2957, 2852, 2808, 1618, 1599 1503, 1453, 1425, 1349, 1327, 1265; HRMS: Calculated for $\mathrm{C}_{14} \mathrm{H}_{17} \mathrm{~N}_{2} \mathrm{O}[\mathrm{M}+\mathrm{H}]^{+}$ 229.1335, observed 229.1332 .
28. Please see the Supplementary Information for details.

29. This observation is in accordance with the result obtained by Sledeski and coworkers (Ref. 20c).

30. 4.5 equivalents of morpholine was used in this control experiment in order to have an equal total amount of base as in the standard conditions. 